\title{
30. SUBSIDENCE AND SEDIMENTATION ANALYSIS OF MARGINAL BASINS: CELEBES SEA AND SULU SEA, LEG 124, SITES 767 AND $768^{1}$
}

\author{
Zehui Huang, ${ }^{2}$ Felix M. Gradstein, ${ }^{2}$ and Keith E. Louden ${ }^{3}$
}

\begin{abstract}
Based on the chronostratigraphy and porosity of the sediments recovered from ODP Sites 767 and 768 drilled in the Celebes Sea and Sulu Sea, respectively, we examine the decompacted sedimentation and basement subsidence rates using a quantitative method. The results of this study help us to recognize several important tectonic events in these two marginal basins which improve understanding of the regional tectonic development. Among the recognized events are: (1) a pronounced increase in decompacted sedimentation rate in the Celebes Sea at $23.4 \mathrm{Ma}$ indicating basin transformation from a larger, more open oceanic setting to a marginal basin; (2) an increased basement subsidence rate in both basins between 10.8 and $8.9 \mathrm{Ma}$ associated with the initiation of the Sulu Trough and the Sulawesi Trough; (3) appearance of a decompacted sedimentation rate peak between 10.0 and $8.9 \mathrm{Ma}$ in both basins, indicating the combined effect of tectonic uplift in the source area and a sea-level drop; (4) uplift of the basement since $2.0 \mathrm{Ma}$, first in the Celebes Sea and then in the Sulu Sea, probably occurring as the result of collision events.
\end{abstract}

\section{INTRODUCTION}

The Sulu and Celebes Seas are two small marginal basins in the west Pacific region, a complicated geotectonic region marked by dynamic arc-arc and arc-continent collision zones, subduction zones, and long strike-slip fault zones. Sites 767 and 770 in the Celebes Sea and Site 768 in the southeast sub-basin of the Sulu Sea penetrated the sediment cover and reached the basaltic basement. The age of basement is early Eocene in the Celebes Sea and early Miocene in the Sulu Sea. The drilling results from Sites 767 and 768 provide a good opportunity to examine the subsidence history of small, marginal basins in the west Pacific region in a quantitative fashion. The subsidence histories of small, marginal basins associated with convergent margins have not been nearly as well studied using quantitative techniques as have basins on passive margins. In this study, we will use decompaction and backstripping techniques to examine changes in decompacted sedimentation rate through time and to analyze the subsidence history on the basis of sediment thickness and chronostratigraphy from Sites 767 and 768 . We expect not only to improve the understanding on the evolution of these two basins, but also to extract information on the regional geotectonism, such as the timing of tectonic events in the region. In addition, this study provides examples of the evolution of small marginal basins along an active margin.

\section{GEOTECTONIC SETTINGS, SEDIMENTATION, AND CHRONOSTRATIGRAPHY}

Figure 1 shows the location of Sites 767 and 768 and outlines the geotectonic settings in the two basins under study. Site 767 was drilled in the Celebes Sea. Hamilton (1977) has shown that the Celebes Sea is nearly encircled by subduction zones. To the south, the Sulawesi Trough is an inactive subduction zone, terminating in the west at the projection of an active left-lateral

\footnotetext{
${ }^{1}$ Silver, E. A., Rangin, C., von Breymann, M. T., et al., 1991. Proc. ODP, Sci. Results, 124: College Station, TX (Ocean Drilling Program).

${ }^{2}$ Department of Geology, Dalhousie University, Halifax, N. S. B3H 3J5, Canada.

${ }^{3}$ Department of Oceanography, Dalhousie University, Halifax, N. S. B3H 3J5, Canada.
}

strike-slip fault system that cuts through Sulawesi, which is a Neogene volcanic arc. The Molucca Sea collision zone, which is nearing completion and features incipient thrusting on its western boundary, lies to the southeast of the Celebes Sea (Hamilton, 1977; Moore and Silver, 1982). The Sangihe Arc, stretching from northeastern Sulawesi to south-central Mindanao, has active volcanoes in its southern and central portions (Hamilton, 1977). In the northeast section of the Celebes Sea, an incipient eastward-directed subduction zone appears to be developing (Moore and Silver, 1982).

Site 768 was drilled in the southeast basin of the Sulu Sea, which is separated from the Celebes Sea by the Sulu Archipelago. Mascle and Biscarrat (1978) demonstrated that the southwest-northeast-trending Sulu Trough that lies north of the Sulu Archipelago is an inactive subduction zone. The Negros Trench along the southeast side of the basin is active, but features very slow subduction (Mascle and Biscarrat, 1978). The Sulu Archipelago is a Neogene volcanic arc.

On-board trace-element geochemical analysis of the basalts recovered from Sites 767 and 768 indicated that the plagioclase-olivine phyric basalts from the Celebes Sea are characteristic of normal mid-ocean ridge basalts (MORB), while the olivine basalts from the Sulu Sea appear to be transitional between MORB and island-arc tholeiites (Rangin, Silver, von Breymann et al., 1990).

Figure 2 summarizes the lithology and chronostratigraphy at Sites 767 and 768 . The sedimentation through time in these two basins can be briefly described as follows:

1. The sediment column penetrated at Site 767 is $786.6 \mathrm{~m}$ thick. Overlying the oceanic basement are middle Eocene reddish brown claystones, indicating an open oceanic environment. The sediments above the basement suggest that the Celebes Sea originated in a position protected from terrigenous sedimentation (Rangin, Silver, von Breymann et al., 1990). Until the early Miocene, the sediments are reddish brown to grayish brown claystone. Miocene sediments are dominated by claystone, siltstone, and some quartz-rich sandstone of turbiditic origin, interbedded with hemipelagic claystone. From late Miocene to the Quaternary time, the Celebes Sea received volcanogenic clayey silt to silty clay and some ash, with carbonate silt to sand. 


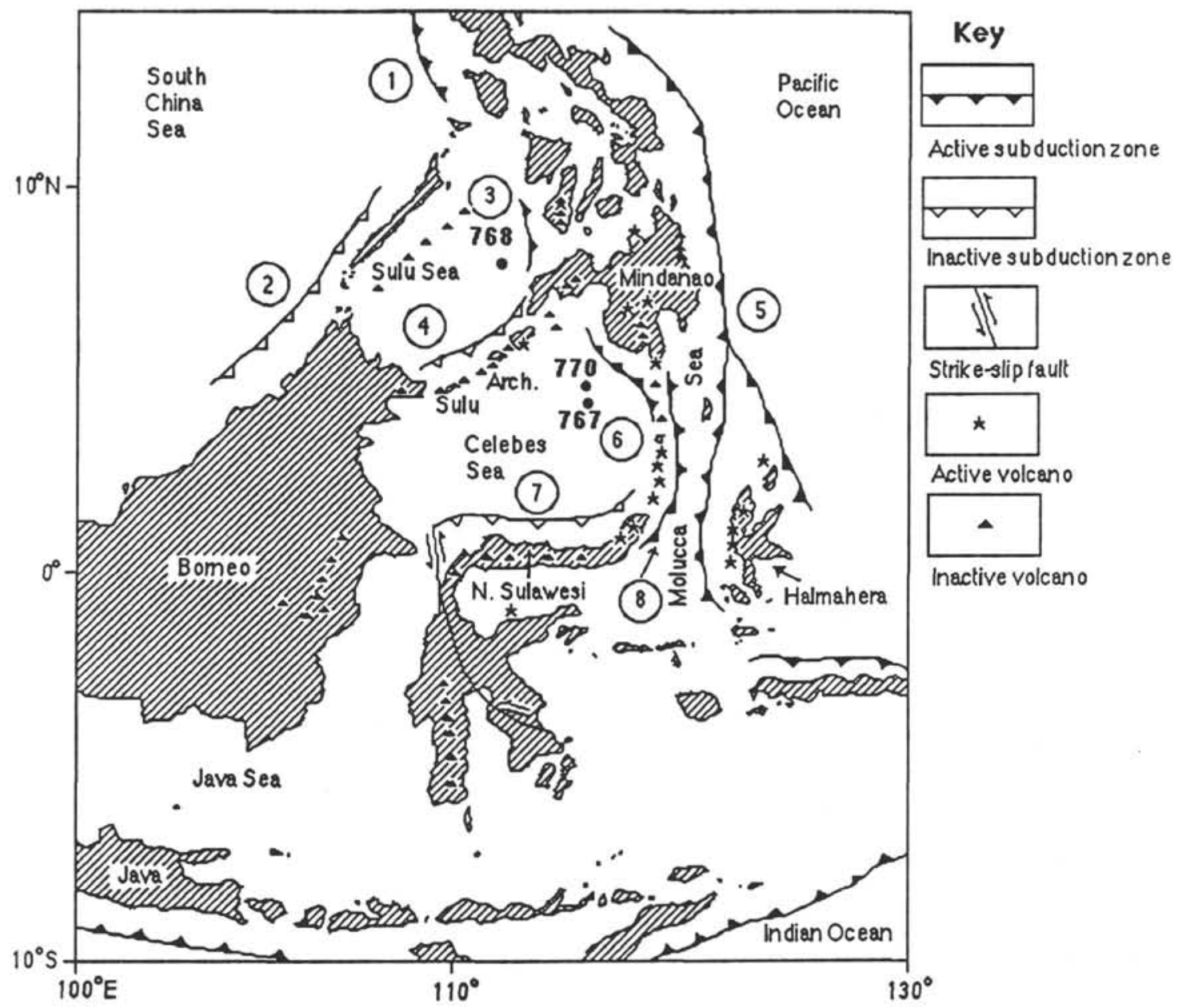

Figure 1. Location of Leg 124 Sites 767, 768, and 770, and the geotectonic settings of the Celebes and Sulu Seas (revised from Hamilton, 1977; Silver and Moore, 1978; and Weissel, 1980). The subduction zones are indicated by the number in circles. 1. Manila Trench; 2. Palawen Trough; 3. Negros Trench; 4. Sulu Trough; 5. Philippine Trench; 6. Cotabato Trench; 7. Sulawesi Trough; 8 . Sangihe Trench.

2. The sediment cover at Site 768 is $1046 \mathrm{~m}$ thick. Upper Miocene sediments are exclusively coarse to fine vitric tuff and lapillistone formed mostly by pyroclastic flow, with some interbedded dark-brown claystone beds representing hemipelagic sedimentation immediately overlying the basaltic basement. Following the active pyroclastic flow phase, there was a period of hemipelagic sedimentation, indicated by brown and grayish green claystone of late early Miocene to middle Miocene age. During most of the middle to late Miocene, however, turbiditic sediments prevailed. The sediments are claystone, siltstone, and thick quartz-rich sandstone with minor chalk of turbiditic origin, interbedded with hemipelagic claystone and ash layers. In the Pliocene, with less turbiditic mass flow, more hemipelagic claystones were deposited along with some volcanic ash. Pelagic carbonate deposition persisted throughout the Pleistocene along with increased input of volcanic ash. The tuff and lapillistone above basement indicate that the Sulu Sea formed in a back-arc environment.

The microfossil and paleomagnetic records of the sediment columns at Sites 767 and 768 (Rangin, Silver, von Breymann et al., 1990) serve as the basis for the chronostratigraphy of the two basins (Fig. 2). At Site 768 more paleomagnetic events and nannofossil datums were detected than at Site 767, which explains why the stratigraphic resolution is higher in the Sulu Sea than in the Celebes Sea. Unfortunately, in both the Sulu Sea and Celebes Sea, the microfossil stratigraphy is not well resolved between 10 and $16 \mathrm{Ma}$ (middle Miocene). A hiatus could have existed between nannofossil Zones NN8 and NN5 at Site 768 around 714.0 meters below sea floor (mbsf) in Core 124-768C-38R. At Site 767, there may be an unrecognized hiatus in this interval. The stratigraphic resolution is poor at both sites in this interval. The numeric age of the fossil datums and paleomagnetic events is from Berggren et al. (1985). A time span from 10.8 to $14.5 \mathrm{Ma}$ is tentatively assigned to the hiatus found at Site 768 .

The age of the basement at Site 767 in the Celebes Sea is determined to be $43.0 \mathrm{Ma}$, according to the occurrence of a radiolarian assemblage resembling the Podocyrtis chalara Zone of late middle Eocene age in the sediments $4 \mathrm{~m}$ above the basement. However, an older basement age of $55 \mathrm{Ma}$ is also possible, as the examination on deep-water agglutinated foraminifers reveals an assemblage of early Eocene age (Kaminski and Huang, this volume). The errors caused by different basement ages will be examined below. The numeric age of the basement in the Sulu Sea is $19 \mathrm{Ma}$, according to both radiolarians (Stichocorys wolffii Zone) and paleomagnetic polarity zones (5Cr to $5 \mathrm{E})$. 

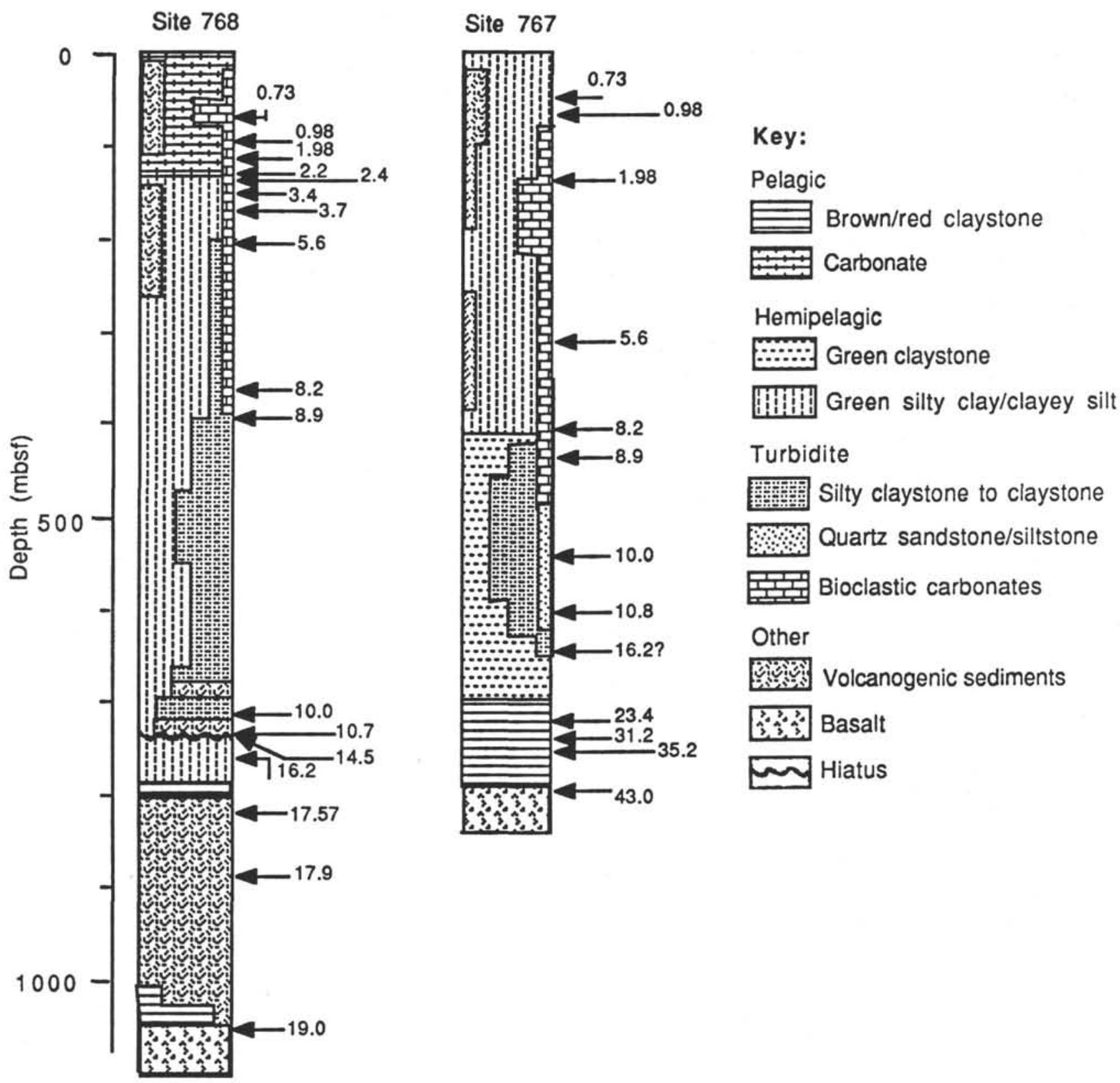

Notes on the numeric age $(\mathrm{Ma})$ in sediment columns (* Radiolarian zone):

\begin{tabular}{|c|c|c|c|c|c|}
\hline 0.73 & Top of Matuyama chron & 0.98 & Bottom of Jaramillo anomaly & 1.98 & Base of NN19 \\
\hline 2.20 & Base of NN18 & 2.40 & Base of NN17 & 3.40 & Base of NN16 \\
\hline 3.70 & Base of NN15 & 5.60 & Base of NN12 & 8.20 & Base of NN11 \\
\hline 8.90 & Base of NN10 & 10.0 & Base of NN9 & 10.8 & Near base of NN8 \\
\hline 14.5 & Near top of NN5? & 16.2 & Base of NN5 & 17.57 & Top of 5D anomaly \\
\hline 17.9 & Bottom of $5 \mathrm{D}$ anomaly & 23.4 & Tase of L. elongata zone* & 31.2 & Base of D. ateuchus zone* \\
\hline 5.2 & Base of T.tuberosa zone & & & & \\
\hline
\end{tabular}

Figure 2. A summary of the sediment columns and chronostratigraphy in Sites 767 and 768 . The numeric age (Ma) of the fossil datum and paleomagnetic event is according to the time scale by Berggren et al. (1985). 


\section{METHODOLOGY AND RESULTS}

In our analysis we employed the computer programs BURSUB and DEPOR (Stam et al., 1987; Gradstein et al., 1989). The program BURSUB calculates the burial, tectonic subsidence, and decompacted sedimentation rates by integrating age, porosity, and paleobathymetric data into a time-depth framework. Corrections are made for the effects of compaction, changes in paleowater depth, and global sea-level changes (Stam et al., 1987).

In this study, decompaction is important for examining decompacted sedimentation rate and studying basement subsidence rate. The information needed for this correction is obtained by using the program DEPOR. This program calculates the best possible linear or curvilinear fit of porositydepth data for each lithological type in a drilling site (Gradstein et al., 1989). Using porosity to correct the effect of compaction assumes that there is a direct relationship between thickness and porosity. Depth-porosity relationships are established using the program DEPOR, using the on-board porosity measurements in claystone and clayey siltstone-tosiltstone at Site 767 and nannofossil marl, tuff, and claystone at Site 768. The depth-porosity relationships of these major lithologies are listed in Table 1. For example, the first term of the linear depth-porosity relationship for siltstone in Site 767 is the siltstone porosity prior to burial (zero depth), which is $87.5 \%$. This value is very close to the measured value of near-surface porosity ( $84 \%)$. The calculated value for nannofossil marl is also in agreement with the observed near-surface porosity of $86 \%$. The second term is the amount by which the zero-depth porosity decreases with burial. These functions were then used by BURSUB for decompacting the major lithologies in time-depth intervals and calculating the decompacted sedimentation rate. The use of laboratory-derived porosity data to build depth-porosity curves can yield much greater accuracy in describing such relationships than converting logging data with the Wyllie equations (Wyllie et al., $1956,1958)$. The decompaction, using depth-porosity relationships determined from observations, is more reliable than borrowing these relationships from a neighboring region or using the default values provided by the program.

The corrections for changes in paleowater depth and global sea level are important for studying basement subsidence rate. Changes in paleowater depth in these two basins are calculated using the technique described by Sclater et al. (1985), which originates from the age-depth relationship for oceanic crust of Sclater et al. (1971) and Parsons and Sclater (1977). The present water depth is 4916.0 meters below sea level (mbsl) at Site 767 and $4384.4 \mathrm{mbsl}$ at Site 768 . The sediment bulk density used to correct the sediment loading is the average of the on-board bulk density measurements, 1.77 $\mathrm{g} / \mathrm{cm}^{3}$ for Site 767 and $1.94 \mathrm{~g} / \mathrm{cm}^{3}$ for Site 768 . The sedimentcorrected basement depth of $5449.5 \mathrm{~m}$ at Site 767 (with a basement age of $43 \mathrm{Ma}$ ) is $654.4 \mathrm{~m}$ deeper than that predicted with Sclater's empirical depth-age relationship from major oceanic basins. For Site 768 a value of $5017.0 \mathrm{~m}$ is $991 \mathrm{~m}$ deeper than predicted for its age of $19 \mathrm{Ma}$. Comparable offsets in other western Pacific marginal basins are also reported by Sclater (1972), Sclater et al. (1976), and Watanabe et al. (1977). The offset implies that the basins in this area may have started rifting at a greater depth. Louden (1980) shows that given a constant $1000 \mathrm{~m}$ offset, Philippine Sea depth and heat-flow values are consistent with the thermal model of normal oceanic basin. It is possible that in a small marginal basin, fast subsidence in the initial stage due to horizontal conduction as shown by Boerner and Sclater (1989) may explain the greater depth of the marginal basins in western
Table 1. Depth-porosity relationship for major lithologies

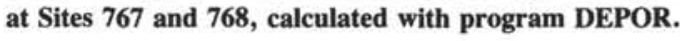

\begin{tabular}{|c|c|c|}
\hline Lithology & $\begin{array}{l}\text { Function } \\
\text { type }\end{array}$ & Function form* \\
\hline $\begin{array}{l}\text { Site } 767 \\
\text { siltstone } \\
\text { claystone }\end{array}$ & $\begin{array}{l}\text { linear } \\
\text { exponential }\end{array}$ & $\begin{array}{l}\phi=0.875-0.8663 \mathrm{D} \\
\phi=0.8321 e^{-0.5709 \mathrm{D}}\end{array}$ \\
\hline $\begin{array}{l}\text { Site } 768 \\
\text { nannofossil marl } \\
\text { claystone } \\
\text { tuff }\end{array}$ & $\begin{array}{l}\text { linear } \\
\text { reciprocal } \\
\text { linear }\end{array}$ & $\begin{array}{l}\phi=0.8486-1.039 \mathrm{D} \\
\phi=1 /(1.185+2.001 \mathrm{D}) \\
\phi=0.62-0.2921 \mathrm{D}\end{array}$ \\
\hline
\end{tabular}

Note: $\phi$ is porosity as fraction of pore space per volume unit, and $\mathrm{D}$ is depth in kilometers.

Pacific region, including the Celebes Sea and Sulu Sea. However, following this initial fast subsidence stage, there are only small effects on subsidence rate relationship. Therefore, the use of a standard depth-age relationship to calculate relative change in depth with age is justified.

Information needed for correcting the effect of long-term changes in eustatic sea level has been taken from Gradstein et al. (1985). Sea-level fluctuations, in time and amplitude, are subject to considerable debate (Steckler, 1984), and the amplitude of the sea-level curve (Gradstein et al., 1985) used in this study is moderately estimated. A test of the effect of the choice of sea-level curve on our basin analysis will be discussed below.

Data on paleowater depth and maximum and minimum changes in eustatic sea-level were also incorporated into BURSUB analysis. For the hiatus found at Site 768, we input a very thin layer of sediment $(1 \mathrm{~m})$ within this time span to meet the continuity requirements. After correcting the effects of eustatic sea-level change, water-depth change and the sediment loading, we can estimate basement subsidence of tectonic origin.

Decompacted sedimentation rates and basement subsidence rates were calculated at Sites 767 and 768 . The basement subsidence rate of time segments presented and discussed in this paper is the average of the basement subsidence rate for the maximum and minimum sea-level changes during the same time interval. To help examine the history of basement subsidence of tectonic origin, we prefer to present basement subsidence rate instead of cumulative subsidence curves. The following results are calculated with the information listed in Appendixes A and B and Table 1.

Figures 3 and 4, respectively, illustrate changes in decompacted sedimentation rate and basement subsidence rate through time at Site 767. In the Celebes Sea, the decompacted sedimentation rate decreased gradually from 43.0 to $23.4 \mathrm{Ma}$ (late middle Eocene to late Oligocene). Following this, the decompacted sedimentation rate increased, reaching an abrupt maximum between 10.0 and $8.2 \mathrm{Ma}$ (late Miocene), when the decompacted sedimentation rate was as high as 19.5 $\mathrm{cm} / \mathrm{k} . \mathrm{y}$.. Another higher decompacted sedimentation rate phase occurred between $1.98 \mathrm{Ma}$ and $0.73 \mathrm{Ma}$ (Pleistocene).

In the Celebes Sea, the basement subsidence rate was high between 43.0 and $35.2 \mathrm{Ma}$ (late middle Eocene to earliest Oligocene), and decreased very rapidly afterward. A possible slight subsidence increase between 10.0 and $8.9 \mathrm{Ma}$ occurs. At around $2.0 \mathrm{Ma}$, the basement subsidence rate became negative, indicating basement uplift.

Figures 5 and 6 present the change of the decompacted sedimentation rate and basement subsidence rate through time at Site 768. In the Sulu Sea we find that during the early stage of the basin development between 19.0 and $17.6 \mathrm{Ma}$ (late early 


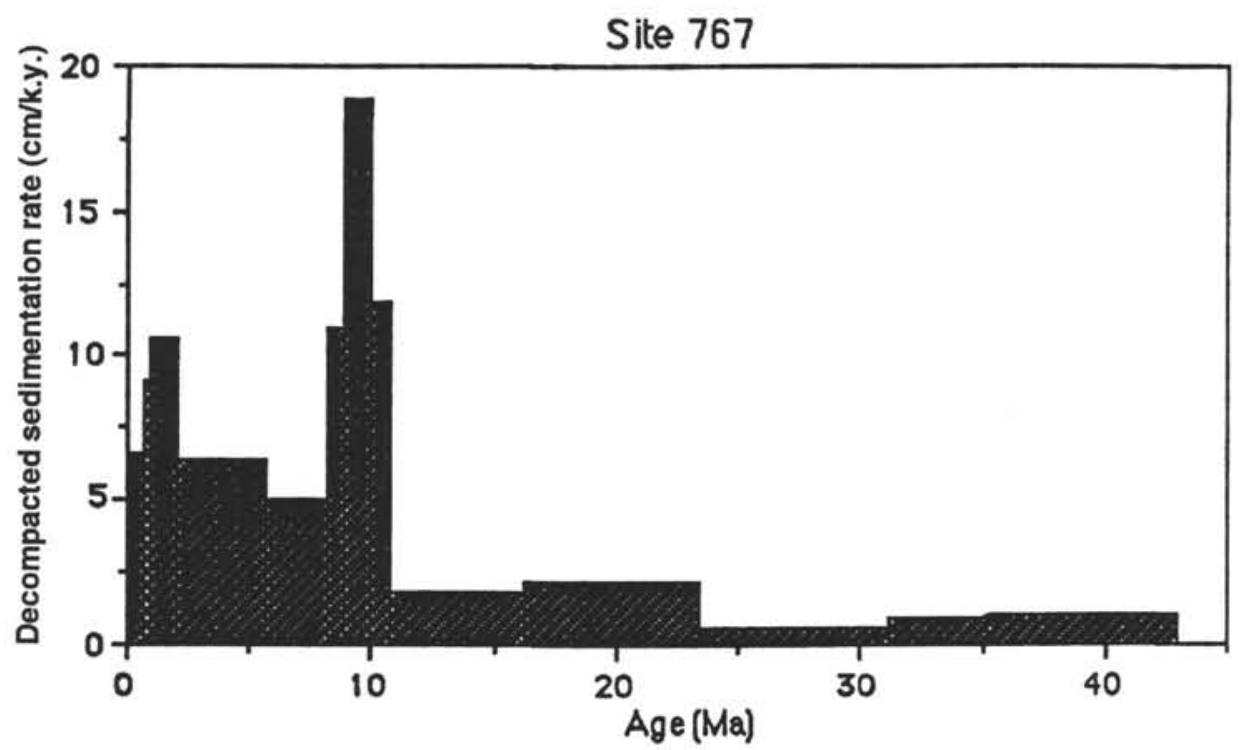

Figure 3. Decompacted sedimentation rates (cm/k.y.) at Site 767, Celebes Sea.

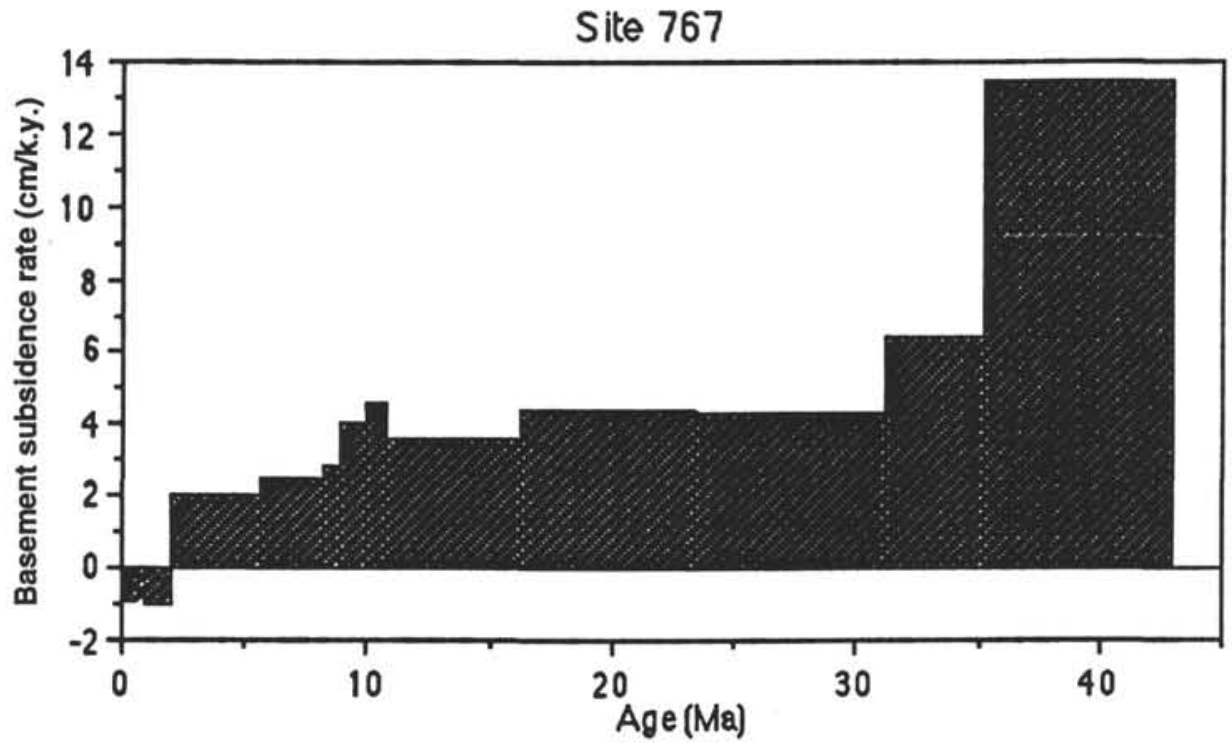

Figure 4. Basement subsidence rates (cm/k.y.) at Site 767, Celebes Sea.

Miocene), the decompacted sedimentation rate was as high as $23-34 \mathrm{~cm} / \mathrm{k} \cdot \mathrm{y}$. The decompacted sedimentation rate decreased between 17.6 and $14.5 \mathrm{Ma}$ (latest early Miocene to early middle Miocene). Between 14.5 and $10.0 \mathrm{Ma}$ (middle Miocene) there was a hiatus, with any sediment deposited during this period being physically removed, most probably by turbiditic currents. A phase with the highest decompacted sedimentation rate in the basin $(43.3 \mathrm{~cm} / \mathrm{k} . \mathrm{y}$.) occurred between 10.0 and $8.9 \mathrm{Ma}$ (early late Miocene), corresponding to the decompacted sedimentation rate peak observed in the Celebes Sea. Other decompacted sedimentation rate peaks appear in the time segments 3.7 to $3.4 \mathrm{Ma}$ and 2.2 to $2.0 \mathrm{Ma}$ in the Pliocene and $1.0 \mathrm{Ma}$ to the present.

In the Sulu Sea, the basement subsidence rate was very high between 19.0 and 17.6 Ma (late early Miocene), followed by very rapid decrease. The basement subsidence rate continued to decrease slowly between 17.6 and $10.7 \mathrm{Ma}$ (late early Miocene and middle Miocene). However, there was an increase in the basement subsidence rate between 10.7 and 10.0 Ma (early late Miocene), almost at the same time as in Site 767. Afterward, it decreased again until 5.6 Ma. Between 5.6 and $1.0 \mathrm{Ma}$, the basement subsidence rate was relatively higher, although there are no obvious peaks. Since $0.7 \mathrm{Ma}$ the basement subsidence rate has been negative.

When comparing the results from the Celebes Sea and the Sulu Sea, we observe synchronous decompacted sedimentation rate peaks in both basins between 10.0 and $8.9 \mathrm{Ma}$, and the basement subsidence rate increases almost synchronously around 10.0 Ma. The most recent stage of basement uplift is nearly synchronous but appears earlier in the Celebes Sea than in the Sulu Sea. 


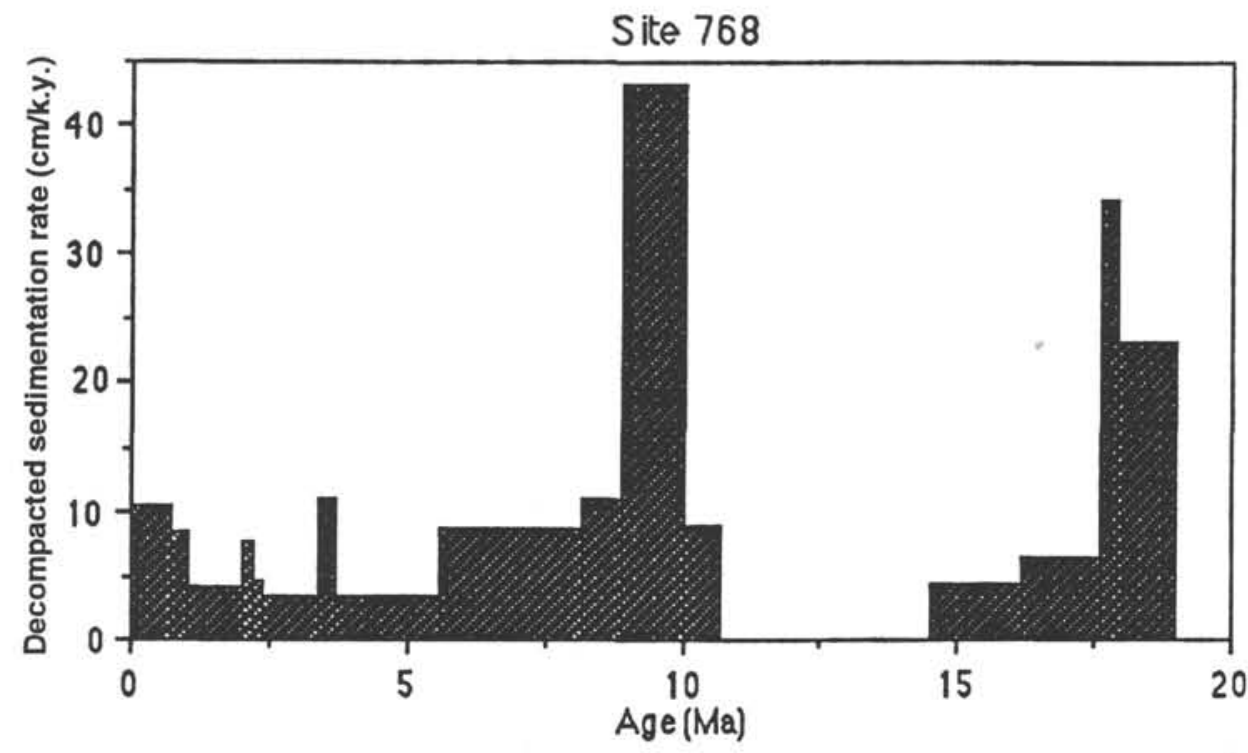

Figure 5. Decompacted sedimentation rates (cm/k.y.) at Site 768, Sulu Sea.

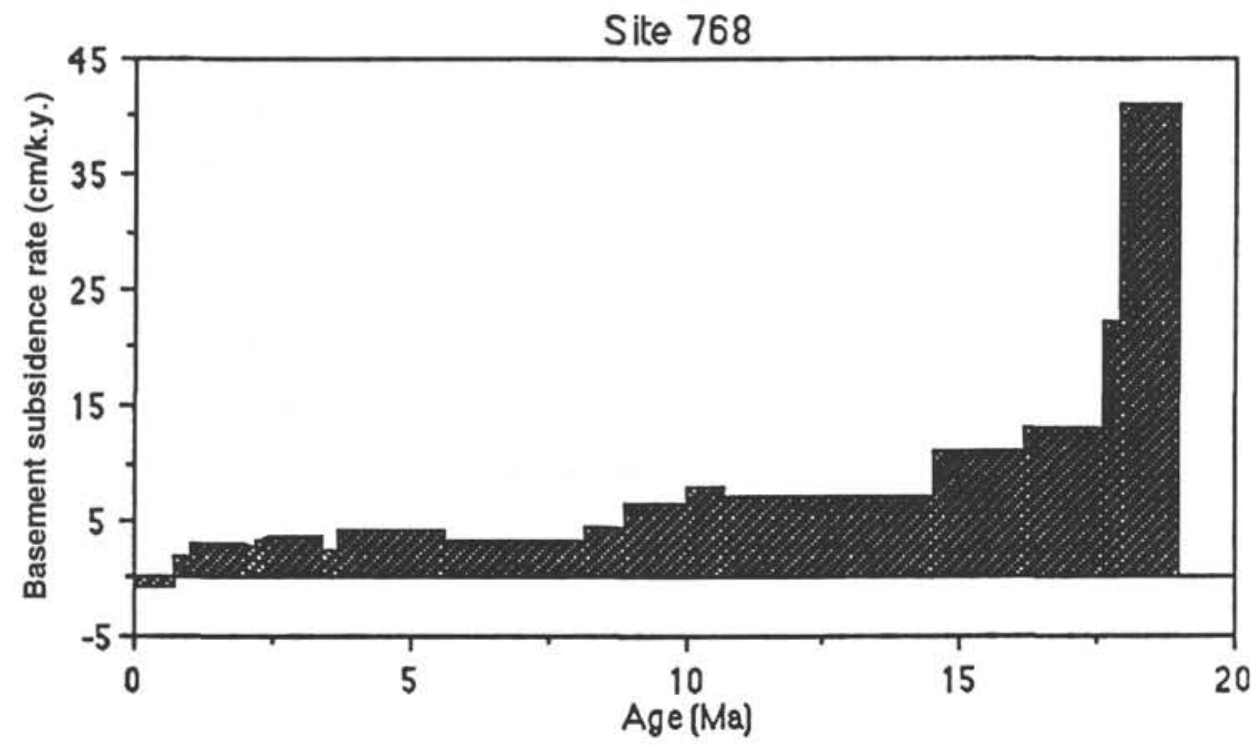

Figure 6. Basement subsidence rates (cm/k.y.) at Site 768, Sulu Sea.

\section{ERROR ANALYSIS AND DISCUSSION}

There are several sources of errors that can affect the results of this study, including the errors in stratigraphy, decompaction correction, and estimates of changes in paleowater depth and sea-level change correction. Prior to further discussion of our results, we shall first assess and analyze the affect of these errors.

The stratigraphic constraint at Site 767 is good for the interval above 598.5 mbsf and younger than middle Miocene $(10.8 \mathrm{Ma})$. The Pleistocene age constraints at this site come from magnetic reversal measurements. The stratigraphic constraint at this site becomes less certain below 598.5 mbsf. The age of the basement has a possible range from as young as 43 Ma based on the radiolarian assemblages (Rangin, Silver, von Breymann, et al., 1990) to $55 \mathrm{Ma}$ according to deep-water agglutinated foraminifer assemblage (Kaminski and Huang, this volume) above the basement. For Site 768 , the stratigraphic constraint is good over the entire section, and the age of basement is much more certain.

For the correction due to changes in paleowater depth, we infer that the errors in the basement age at Site 767 may introduce some error to the analysis in the Celebes Sea. With a basement age of $55 \mathrm{Ma}$, the changes in paleowater depth are somewhat different from those with a basement age of $43 \mathrm{Ma}$. Figure 7 compares the changes in paleowater depth. We find that the differences in the paleowater depth become small between these two estimations from $16 \mathrm{Ma}$ to present. With an older basement age (55 Ma) and using paleowater depth information obtained with this basement age, we recalculated basement subsidence rates at Site 767 . The results are presented in Figure 8 to compare with the results from the data listed in Appendix A and Table 1 (Fig. 4). It is obvious that there is no substantial difference 


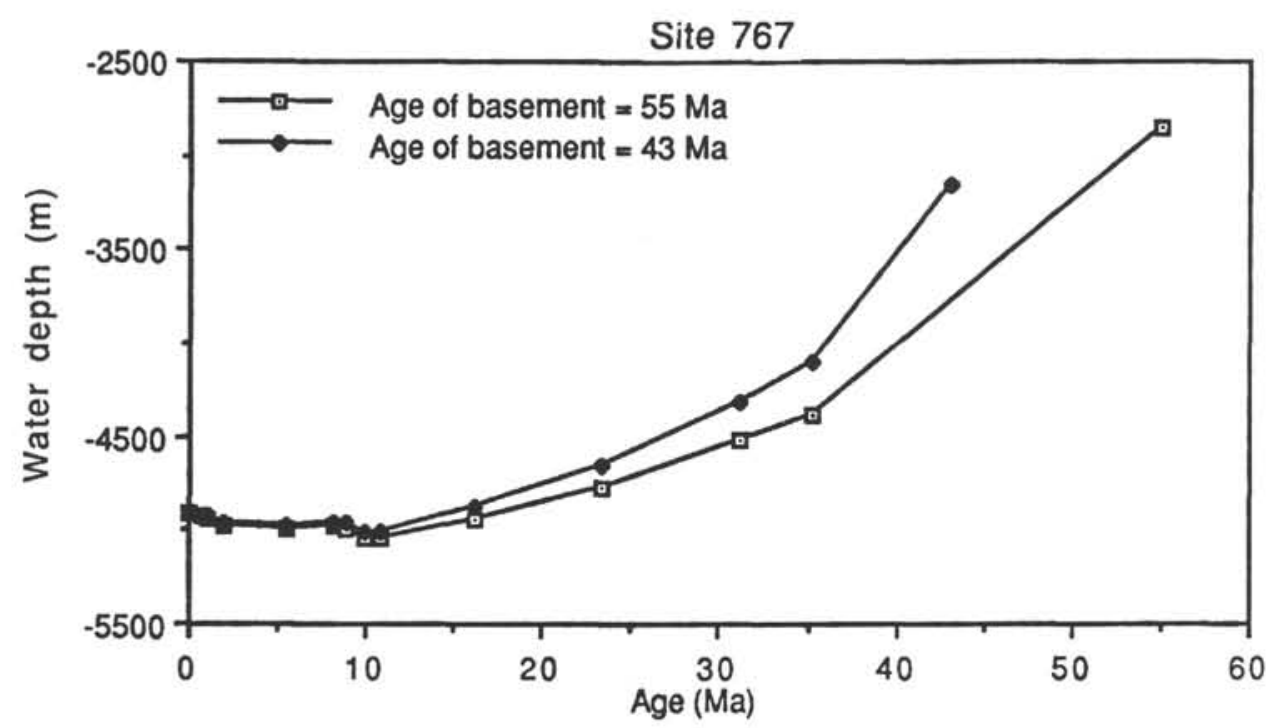

Figure 7. Paleowater depth with time estimated from different basement ages at Site 767, Celebes Sea.

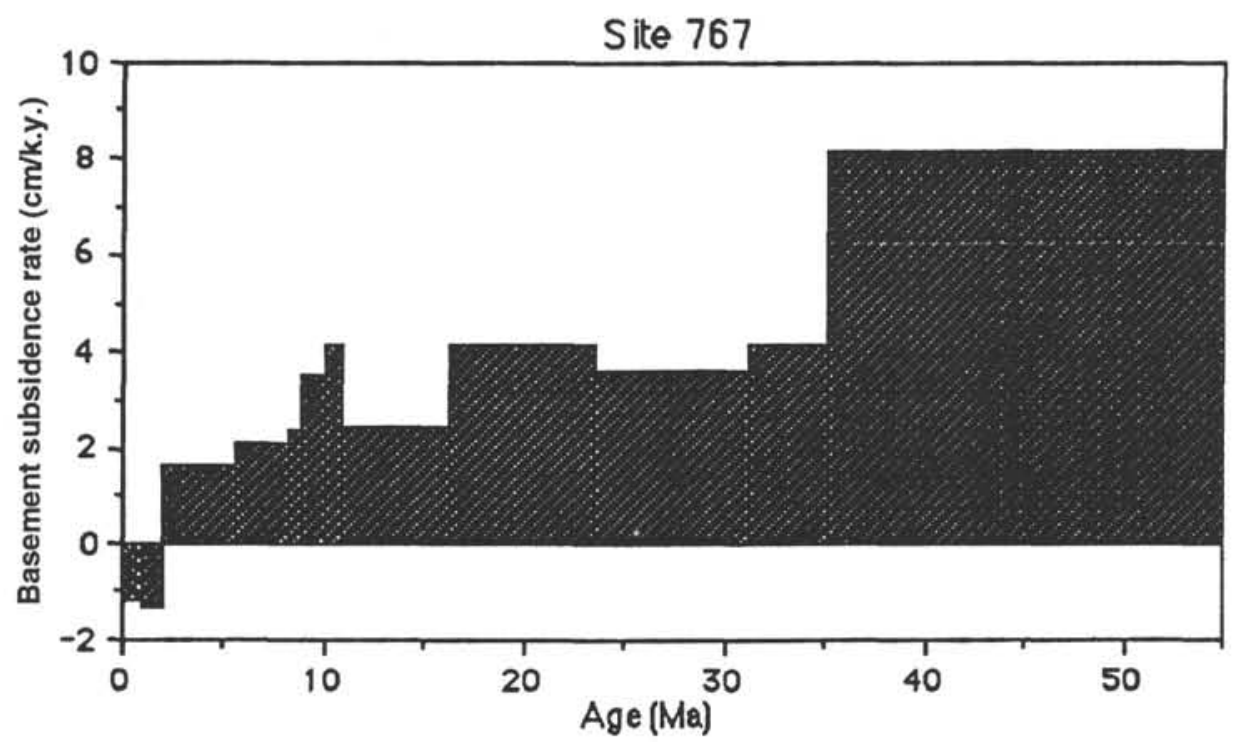

Figure 8. Changes in basement subsidence rates $(\mathrm{cm} / \mathrm{k} . \mathrm{y}$.) at Site 767 , Celebes Sea, using an older basement age of $55 \mathrm{Ma}$.

between these two figures for the time interval from middle Miocene (around $16 \mathrm{Ma}$ ) to present. The peak of basement subsidence rates around 10.8 to $8.9 \mathrm{Ma}$ still appears on Figure 8 and the basement subsidence rates from $2.0 \mathrm{Ma}$ to present are also negative in Figure 8.

The information for decompaction at these two sites has been assembled with sediment porosity measurements. As discussed before, the depth-porosity relationships for different lithologies have few uncertainties. Even if there were error in the decompaction, it would be primarily caused by the high zero-depth porosities in the depth-porosity functions for some lithologies such as silt and nannofossil marl. For an error analysis at Site 767 we changed the depth-porosity relationship for siltstone from $\phi=0.875-0.8663 D$ to $\phi=0.775-$ $0.8263 D$ and that for claystone from $\phi=0.8321 e^{-0.5709} D$ to $\phi$ $=0.7321 e^{-0.5309} \mathrm{D}$. Through this change, the zero-depth poros- ities in both of the new relationships are $10 \%$ lower than in the original relationship and the coefficients for porosity decrease with depth are decreased correspondingly. A $10 \%$ error for zero-porosity in the relationship is the largest we can expect with our method. The reason that we input a reduction in zero-depth porosity for the error analysis is that the zerodepth porosities in the original relationship for siltstone and claystone at this site have been as high as $87.5 \%$ and $83.2 \%$, respectively. With these new decompaction parameters we recalculated the basement subsidence rate. The results are listed in Table 2 (Column B) to compare with the basement subsidence rate (Column A) calculated with the original relationships as shown in Table 1 . This comparison shows that, with two sets of decompaction parameters, the changes of basement subsidence rate through time display the same trend. 
Table 2. Comparison of changes in basement subsidence rates $(\mathrm{cm} / \mathbf{k . y}$.) with different corrections on compaction and longterm changes in sea level at Site $\mathbf{7 6 7}$, Celebes Sea.

\begin{tabular}{lrrr}
\hline Age interval (Ma) & \multicolumn{1}{c}{ A } & \multicolumn{1}{c}{ B } & \multicolumn{1}{c}{ C } \\
\hline $0.0-0.7$ & -0.88 & -0.45 & -0.84 \\
$0.7-1.0$ & -0.84 & -0.39 & -0.53 \\
$1.0-2.0$ & -0.95 & -0.41 & -0.80 \\
$2.0-5.6$ & 2.01 & 2.25 & 2.12 \\
$5.6-8.2$ & 2.51 & 2.60 & 2.64 \\
$8.2-8.9$ & 2.83 & 2.90 & 3.31 \\
$8.9-10.0$ & 4.00 & 3.79 & 4.09 \\
$10.0-10.8$ & 4.59 & 4.22 & 4.82 \\
$10.8-16.2$ & 3.61 & 3.52 & 3.61 \\
$16.2-23.4$ & 4.36 & 4.13 & 4.32 \\
$23.4-31.2$ & 4.29 & 4.20 & 4.40 \\
$31.2-35.2$ & 6.41 & 6.25 & 6.46 \\
$35.2-43.0$ & 13.41 & 13.11 & 13.40 \\
\hline
\end{tabular}

Note:

A. Basement subsidence rates with the depthporosity relationships in Table 1 for decompaction and with the sealevel curve compiled by Gradstein et al. (1985) for sea-level change correction.

B. Basement subsidence rates with the changed depth-porosity relationships $(\phi=0.775$ $-0.8263 \mathrm{D}$ for siltstone, and $\phi=$ $0.7321 e^{-0.5309 D}$ for claystone) for decompaction and with the sealevel curve compiled by Gradstein et al. (1985) for sea-level change correction.

C. Basement subsidence rates with the depthporosity relationships in Table 1 for decompaction and with the sealevel curve by Haq et al. (1987) for sea-level change correction.

To test the effect of the choice of sea-level curve on our analysis, we used the high-amplitude sea-level curve of Haq et al. (1987) for the sea-level change correction. For comparison, Column A in Table 2 shows basement subsidence rates at Site 767 using the sea-level curve compiled by Gradstein et al. (1985), while Column C in Table 2 shows those using the curve by Haq et al. (1987). This comparison illustrates that for Site 767 the tectonic subsidence corrected using two different sea-level curves displays a similar trend with only minor differences. The same is true for Site 768. Thus, choice of sea-level curve makes little difference in our analysis for the depth of the sites.

From the above examination and discussion, we conclude that the changes in decompacted sedimentation rate and basement subsidence rate through time displayed in Figures 3, 4,5 , and 6 for the two marginal basins present a valid reflection of the geological evolution of the Celebes and Sulu Seas, at least for the time interval from middle Miocene (around $16 \mathrm{Ma}$ ) to present.

The lower decompacted sedimentation rate in the Celebes Sea before 23.4 Ma may reflect more open oceanic conditions. At $23.4 \mathrm{Ma}$ the decompacted sedimentation rate substantially increased. This increase may indicate that around $23.4 \mathrm{Ma}$, or a little later, the Celebes Sea began a transformation into a marginal basin or at least was near enough to the source area to receive a larger input of sediment or that the source of sediment supply increased. As most of the terraces now surrounding the Celebes Sea are predominantly Tertiary arc volcanic rocks (e.g., Mindanao, North Sulawesi, and Sulu Ridge), the most likely terrigeneous source would be Borneo, where strata of the Crocker Formation and its equivalent are widely exposed (Hamilton, 1979), even though Site 767 is nearer to Mindanao than to Borneo. Therefore, in the process of being transformed to a marginal basin, the Celebes Sea may have moved from east to west. According to Katili (1978), the Celebes Sea formed as a marginal basin as a result of the westward thrust of the Sulawesi arc. Otofuji et al. (1981) suggested a more than $90^{\circ}$ clockwise rotation of the northern arm of Sulawesi, starting no later than middle Miocene, which may have played a crucial role in this transformation. Our results indicate that this process may have been initiated around $23 \mathrm{Ma}$.

For the Sulu Sea, the initial decompacted sedimentation rate peak $(19.0-17.6 \mathrm{Ma})$ is due to the sedimentation of pyroclastic flows soon after the sea opened. This period appears to record a stage of rapid subsidence, as indicated by the corresponding high basement subsidence rate.

In the middle Miocene $(10.0-8.9 \mathrm{Ma})$, the highest decompacted sedimentation rate peaks appeared both in the Sulu Sea and Celebes Sea. In the Sulu Sea, it is as high as $43 \mathrm{~cm} / \mathrm{k} . \mathrm{y}$. During this period, both basins received fine-grained and quartz-rich turbidites. The sedimentation rate is so high that the large quantity of material probably came from an uplifted source area during a period of sea-level drop at around 10.0 $\mathrm{Ma}$, as suggested by Haq et al. (1987).

The basement subsidence rate increased both in the Celebes Sea between 10.8 and $8.9 \mathrm{Ma}$, and in the Sulu Sea between 10.7 and $10.0 \mathrm{Ma}$. The increase of the basement subsidence rate in both basins may have resulted from the initiation of the Sulu Trough and the Sulawesi Trough as subduction zones, the latter due to the clockwise rotation of Sulawesi around $11 \mathrm{Ma}$.

Volcanic ash poured into both the Celebes and Sulu Seas beginning at $6 \mathrm{Ma}$ or earlier (Fig. 2), from the volcanoes around the two basins (Fig. 1). Among these ash sources, the volcanoes on the Sulu Archipelago were activated by the southward subduction of the small Sulu Plate along the Sulu Trough, but the volcanoes on northeast Sulawesi may have been activated by either the southward subduction of the Celebes Plate along the Sulawesi Trough and/or by earlier subduction of the Molucca Sea beneath the Celebes Sea (Silver and Moore, 1978). Other sources include the volcanoes (inactive and active) on the Sangihe Arc, stretching from northeastern Sulawesi to south-central Mindanao and, less importantly, volcanoes in the southern Philippines.

The decompacted sedimentation rate peaks of late Pliocene and Quaternary (since $2.4 \mathrm{Ma}$ ) observed in both Celebes and Sulu Seas also occur in many other basins, where they are accounted for by the initiation of glaciation as well as compressional intraplate tectonism, producing local to basin edge uplift (Cloetingh et al., 1990). Between 2.4 and 2.0 Ma the basement subsidence rate was relatively low, as observed at Site 768 , which may correspond to a period of shallowing of the surrounding sills such as the Sulu Ridge and an uplift of the source area. The shallowing of the sill isolated the Sulu Sea from the deep waters of the Pacific Ocean and initiated carbonate sedimentation. In the Celebes Sea, the Quaternary decompacted sedimentation rate peak $(2.0-1.0 \mathrm{Ma})$ is coincident with the negative basement subsidence rate. This may be the evidence that the basins themselves were uplifted along with the surrounding terraces. When the basins were uplifted, more material with more volcanic ash from the surrounding terraces poured into the basins as a result of collision in the Molucca Sea (Moore and Silver, 1982).

Negative basement subsidence rates (i.e., basement uplift) characterized the Celebes Sea starting at $2.0 \mathrm{Ma}$ and the Sulu Sea starting at $0.7 \mathrm{Ma}$. We consider that the probable cause of the uplift is collision in the Molucca Sea. We date the collision event in the Molucca Sea (Moore and Silver, 1982) at around $3.0-2.5 \mathrm{Ma}$. 


\section{SUMMARY}

The Celebes and Sulu Seas are two marginal basins of different origins in the western Pacific region. The Celebes Sea originated in a more open oceanic setting with a low decompacted sedimentation rate in its early stages, and became a marginal basin environment after $23.4 \mathrm{Ma}$. In contrast, the Sulu Sea opened rapidly in an intra-arc or back-arc position, with rapid deposition of pyroclastic flows between 19 and $17 \mathrm{Ma}$.

In spite of their different origins, our analysis using decompaction and backstripping techniques, on the basis of chronostratigraphic paleobathymetric and porosity data from Sites 767 and 768 , indicates that these two basins have undergone similar changes since the middle Miocene, reflecting their regional tectonic evolution. The major changes and associated times are:

1. There was an increase in basement subsidence rate in both basins between 10.8 and 8.9 Ma (Figs. 4 and 6), associated with the initiation of the Sulu Trough and the Sulawesi Trough. The formation of these troughs suggests a period of strong north - south compression.

2. Between 10.8 and $8.9 \mathrm{Ma}$, both basins received a large influx of turbidites (Figs. 3 and 5), a result of the uplifting of the source area and sea-level drop.

3. Uplift of the basement started at 2.0 Ma in the Celebes Sea and at $0.7 \mathrm{Ma}$ in the Sulu Sea as the result of collision in the Molucca Sea prior to 2.0 Ma.

\section{ACKNOWLEDGMENTS}

We thank the Shipboard Scientific Party of Leg 122 for the cooperative scientific effort that made this study possible. We are grateful to M. A. Williamson, R. S. Morrison, and E. A. Silver and an anonymous reviewer for their manuscript reviews and suggestions. Financial support for Z. H. was provided by a Canadian NSERC Collaborative Special Project Grant, and a University Research Grant from Imperial Oil (Canada).

\section{REFERENCES}

Berggren, W. A., Kent, D. V., Flynn J. J., and Van Couvering, J. A., 1985. Cenozoic geochronology. Geol. Soc. Am. Bull., 96:14071418.

Boerner, S. T., and Sclater, J. G., 1989. Approximate solutions for the heat loss in small marginal basins. In Wright, J. A., and Louden, K. E. (Eds.), Handbook of Seafloor Heat Flow: Boca Raton (CRC Press), 231-255.

Cloetingh, S., Gradstein, F. M., Kool, H., Grant, A. C., and Kaminski, M., in press. Plate reorganization: a cause of rapid late Neogene subsidence and sedimentation around the North Atlantic? J. Geol. Soc. London.

Gradstein, F. M., Agterberg, F. P., Brower, J., and Schwarzacher, W., 1985. Quantitative Stratigraphy: Dordrecht (UNESCO and D Reidel Publ. Co.)

Gradstein, F. M., Fearon, J. M., and Huang, Z., 1989. BURSUB and DEPOR version 3.50-two FORTRAN 77 programs for porosity and subsidence analysis. Open-File Rep.-Geol. Surv. Can. 1283:1-10.

Hamilton, W., 1977. Subduction in the Indonesian region. In Talwani, M., and Pitman, W. C., III (Eds.), Island Arcs, Deep Sea Trenches, and Back-arc Basins. Am. Geophys. Union, Maurice Ewing Ser., 1:15-31.

1979. Tectonics of the Indonesian region. Geol. Surv. Prof Pap. U.S., No. 1078.
Haq, B. U., Hardenbol, J., and Vail, P. R., 1987. Chronology of fluctuating sea levels since the Triassic. Science, 235:1156-1167.

Katili, J. A., 1978. Past and present geotectonic position of Sulawesi, Indonesia. Tectonophysics, 45:289-322.

Leg 124 Shipboard Scientific Party, 1989. Origins of marginal basins. Nature, 338:380-381.

Louden, K. E., 1980. The crustal and lithospheric thickness of the Philippine Sea as compared to the Pacific. Earth Planet. Sci. Lett., 50:275-288.

Mascle, A., and Biscarrat, P. A., 1978. The Sulu Sea: a marginal basin in Southeast Asia. In Watkins, J. S., Montadert, L., and Dickerson, P. W. (Eds.), Geological and Geophysical Investigations of the Continental Margins: AAPG Mem., 29:373-381.

Moore, G. F., and Silver E. A., 1982. Collision processes in the Northern Molucca Sea. In Hayes, D. E. (Ed.), The Tectonic and Geologic Evolution of Southeast Asian Seas and Islands (Pt. 2). Am. Geophys. Union, Geophys. Monogr. Ser., 27:360-372.

Otofuji, Y., Sasajima, S., Nishimura, S., Dharma, A., and Hehuwat, F., 1981. Paleomagnetic evidence for clockwise rotation of the northern arm of Sulawesi, Indonesia. Earth Planet. Sci. Lett., $54: 272-280$.

Parsons, B., and Sclater, J. G., 1977. An analysis of variation of ocean floor bathymetry and heat flow with age. J. Geophys. Res., 82:803-827.

Rangin, C., Silver, E. A., von Breymann, M. T., et al., 1990. Proc. $O D P$, Init. Repts, 124: College Station, TX (Ocean Drilling Program).

Sclater, J. G., 1972. Heat flow and elevation of the marginal basins of the Western Pacific. J. Geophys. Res., 77:5685-5696.

Sclater, J. G., Anderson, R. N., and Bell, M. L., 1971. Elevation of ridges and evolution of the central eastern Pacific. J. Geophys. Res., 76:7888-7915.

Sclater, J. G., Karig, D., Lawver, L. A., and Louden, K. E., 1976. Heat flow, depth and crustal thickness of the marginal basins of the South Philippine Sea. J. Geophys. Res., 81:309-318.

Sclater, J. G., Meinke, L., Bennett, A., and Murphy, C., 1985. The depth of the ocean through the Neogene. In Kennett, J. P. (Ed.), The Miocene Ocean: Paleoceanography and Biogeography. Mem. Geol. Soc. Am., 163:1-20.

Silver, E. A., and Moore, J. C., 1978. The Molucca Sea collision zone, Indonesia. J. Geophys. Res., 83:1581-1691.

Stam, B., Gradstein, F. M., Lloyd, P., and Gillis, D., 1987. Algorithms for porosity and subsidence history. Computers and Geosci., 13:317-349.

Steckler, M. S., 1984. Changes in sealevel. In Holland, H. D., and Trendall, A. F. (Eds.), Patterns of Change in Earth Evolution: New York (Springer-Verlag), 103-121.

Watanabe, T., Langseth, M. G., and Anderson, R. N., 1977. Heat flow in back-arc basins of the western Pacific. In Talwani, M., and Pitman, W. C., III (Eds.), Island Arcs, Deep Sea Trenches and Back-arc Basins, Am. Geophys. Union, Maurice Ewing Ser., 1:137-161.

Weissel, J. K., 1980. Evidence for Eocene oceanic crust in the Celebes Basin. In Hayes, D. E. (Ed.), The Tectonic and Geologic Evolution of Southeast Asian Seas and Islands. Am. Geophys. Union, Geophys. Monogr. Ser., 23:37-47.

Wyllie, M.R.J, Gregory, A. R., and Gardner, L. W., 1956. Elastic wave velocities in heterogeneous and porous media. Geophysics, 21:41-70.

Wyllie, M.R.J, Gregory, A. R., and Gardner, G.H.F., 1958. An experimental investigation of factors affecting elastic wave velocities in porous media. Geophysics, 23:459-493.

Date of initial receipt: 28 May 1990

Date of acceptance: 1 March 1991

Ms 124B-177 
Appendix A. Data for decompaction and backstripping, Site 767, Celebes Sea.

\begin{tabular}{rrcccl}
\hline $\begin{array}{c}\text { Age } \\
(\mathrm{Ma})\end{array}$ & $\begin{array}{c}\text { Depth } \\
\text { (mbsf) }\end{array}$ & $\begin{array}{c}\text { Water depth } \\
\text { (mbsl) }\end{array}$ & $\begin{array}{c}\text { Sea level }(\mathrm{m}) \\
\text { (maximum) }\end{array}$ & $\begin{array}{c}\text { Sea level }(\mathrm{m}) \\
\text { (minimum) }\end{array}$ & $\begin{array}{c}\text { Underlying } \\
\text { lithology }\end{array}$ \\
\hline 0.0 & 0.0 & 4916 & 0.0 & 0.0 & siltstone \\
0.73 & 48.8 & 4930 & 0.0 & 1.8 & siltstone \\
0.98 & 66.4 & 4935 & 0.0 & 2.0 & siltstone \\
1.98 & 149.5 & 4964 & 0.0 & 5.0 & siltstone \\
5.6 & 311.8 & 4973 & 0.0 & 9.0 & claystone \\
8.2 & 393.2 & 4952 & 0.0 & 9.5 & claystone \\
8.9 & 435.9 & 4959 & 0.0 & 10.0 & claystone \\
10.0 & 553.5 & 5007 & 0.0 & 11.0 & claystone \\
10.8 & 598.5 & 5013 & 0.0 & 13.0 & claystone \\
16.2 & 645.0 & 4870 & 0.0 & 23.0 & claystone \\
23.4 & 720.0 & 4659 & 0.0 & 30.0 & claystone \\
31.2 & 739.0 & 4324 & 0.0 & 35.0 & claystone \\
claystone \\
45.2 & 753.0 & 4109 & 0.0 & 41.0 & \\
\hline
\end{tabular}

Appendix B. Data for decompaction and backstripping, Site 768, Sulu Sea.

\begin{tabular}{lrcccl}
\hline $\begin{array}{c}\text { Age } \\
(\mathrm{Ma})\end{array}$ & $\begin{array}{r}\text { Depth } \\
\text { (mbsf) }\end{array}$ & $\begin{array}{c}\text { Water depth } \\
\text { (mbsl) }\end{array}$ & $\begin{array}{c}\text { Sea level }(\mathrm{m}) \\
\text { (maximum) }\end{array}$ & $\begin{array}{c}\text { Sea level }(\mathrm{m}) \\
\text { (minimum) }\end{array}$ & $\begin{array}{c}\text { Underlying } \\
\text { lithology }\end{array}$ \\
\hline 0.0 & 0.0 & 4384 & 0.0 & 0.0 & marl \\
0.73 & 76.3 & 4401 & 0.0 & 1.8 & marl \\
0.98 & 90.6 & 4399 & 0.0 & 2.0 & marl \\
1.98 & 118.7 & 4374 & 0.0 & 5.0 & claystone \\
2.2 & 128.1 & 4370 & 0.0 & 6.0 & claystone \\
2.4 & 133.0 & 4365 & 0.0 & 6.5 & claystone \\
3.4 & 151.5 & 4333 & 0.0 & 7.0 & claystone \\
3.7 & 169.0 & 4330 & 0.0 & 8.0 & claystone \\
5.6 & 203.4 & 4263 & 0.0 & 9.0 & claystone \\
8.2 & 358.1 & 4225 & 0.0 & 9.5 & claystone \\
8.9 & 391.2 & 4208 & 0.0 & 10.0 & claystone \\
10.0 & 714.2 & 4340 & 0.0 & 11.0 & claystone \\
10.7 & 734.0 & 4311 & 0.0 & 12.0 & claystone \\
14.5 & 735.0 & 4045 & 0.0 & 16.0 & claystone \\
16.2 & 758.5 & 3903 & 0.0 & 23.0 & tuff \\
17.57 & 816.0 & 3770 & 0.0 & 23.5 & tuff \\
17.9 & 887.0 & 3762 & 0.0 & 24.0 & tuff \\
19.0 & 1046.8 & 3491 & 0.0 & 28.0 & \\
\hline
\end{tabular}

